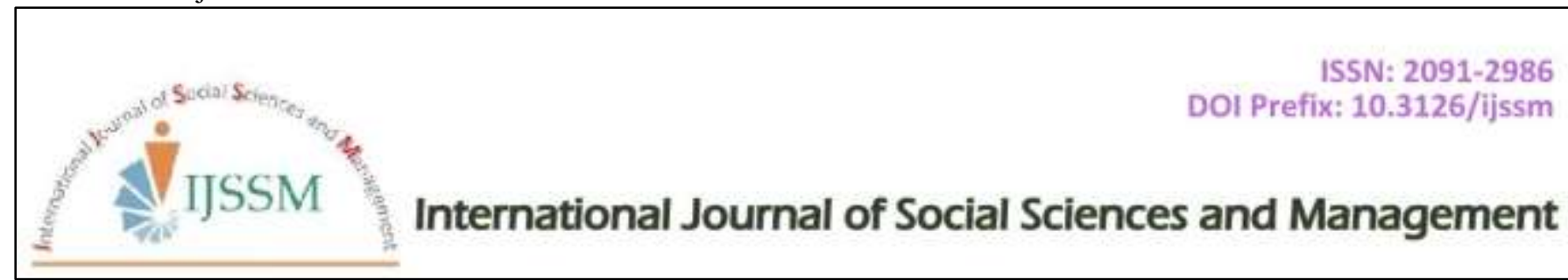

Mini Review

\title{
DEMOGRAPHIC CHANGES AND GROWTH OF POPULATION IN UTTAR PRADESH: TRENDS AND STATUS
}

\author{
Sandeep Kumar Baliyan* \\ Giri Institute of Development Studies (GIDS), Lucknow - 226024 \\ *Email: sonubaliyan@gmail.com / sandeep_baliyan@yahoo.com
}

\begin{abstract}
In this paper we are examines the structure change and population growth trend in Uttar Pradesh. Uttar Pradesh is the most populous state in the country, accounting for 16.4 percent of the country's population. The structure of state income shows that the contribution of primary sector has declined to 41 percent of the state income, though the sector still sustain 73 percent of the total working force. Availability of land \& natural resource and environment play an important role in the development of any country or states. But utilization of these resources and best use of economic development is possible only by people. People are searching and best utilize these natural resources according to their needs. The demographics population of Uttar Pradesh is a multifarious subject, which is undergoing dynamic change. To understand the population it is very important to understand its all charterstic in which age composition has an important role. The working population and work participation rate highlights the occupational distribution of a states. The information is essential for calculating state domestic product at factor cost popularly known as "State Income" for important tertiary sectors by adopting statistical methods of interpolation/extrapolation. The generally well performing states are Kerala, Delhi, Himachal Pradesh, Goa, and Punjab, which occupy the first five places in the years. On the other hand, Bihar, Jharkhand, Madhya Pradesh, Uttar Pradesh, Orissa, Rajasthan, and Chhattisgarh appear at the bottom of the list in the years. Thus, despite some catching-up witnessed in the states with low human development, the progress has not been rapid enough to change the inter se ranking radically.
\end{abstract}

Keywords: HDI; Population growth; Density; Literacy; Sex ratio.

\section{Introduction}

Uttar Pradesh is the most populous state in the country, accounting for 16.4 percent of the country's population. It is also the fourth largest state in geographical area covering 6.88 percent of the country's geographical area, encompassing 2,43,290 square kilometers and comprising of 75 districts, 901 development blocks and 200 million inhabited villages. The density of population in the state is 829 people per square kilometers as against 382 in the country. The total population of the state was 8.8 crores in 1971. It increased to 11.1 crores in 1981 and then reported to be 19.9 crores in 2011 . The increase, in population in these two decades was almost identical at 25 percent. As against this, the national population shows a declining trend from 25 percent in 1971-81 to 23.8 percent in 1981-91 and during 2001-2011 period population decade growth declining in 20.0 percent. Population percentage forms has remained higher than that of the national (https://en.wikipedia.org/wiki/Uttar_Pradesh).

The pace of urbanization has been lower in the state. The level of urbanization has also been lower than most other states. The numbers of urban centers with more than one lakh population have grown slowly over the last thirty years. The growth of urban centers with population less than five thousand have, on the other hand, have grown more significantly and these centers have grown in larger numbers in the western part of the state.

The structure of state income shows that the contribution of primary sector has declined to 41 percent of the state income, though the sector still sustain 73 percent of the total working force. This shows the continued pressure of the working population in the primary sector. The share of secondary sector, on the other hand, has gone up to 20 percent of the total state income which now employ 9 percent of the total workers in the state. It thus shows that the Uttar Pradesh's growth has been more capital intensive than labor intensive, more urban based than rural based and the shift income from 
primary to other sectors is not accompanied by a corresponding change in employment pattern (Agarwal, 2013).

The distinguishing feature of Uttar Pradesh's economy is its regional imbalances. In terms of economic indicators like agricultural productivity, infrastructural facilities, industrial growth, the Uttar Pradesh's economy can be categorized into five regions; Western, Eastern, Central, Ruhelkhand and Hill. The Western Uttar Pradesh is agriculturally prosperous. It is relatively industrialized and has seen a greater degree of urbanization. At the other end is Bundelkhand. Low agricultural growth, less number of industrial units, the lesser gross value of industrial products marks tout his region as the least developed in the state.

Almost all social indicators of the state shows that the state stands on a 13th or 14th position among the sixteen major States. Bihar and in some cases Orissa, are the only two states which lag behind U.P. in terms of social development indicators like medical facilities, teacher-pupil ratio in primary schools, birth rate, death rate, infant mortality rate, literacy, per capita income, electrification of villages, per capita power consumption, etc. Uttar Pradesh is often seen as a case study of development in a region of India that currently lag behind other parts of the country in terms of a number of important aspects of wellbeing and social progress. Their region consists of Bihar, Madhya Pradesh, Rajasthan and Uttar Pradesh. There are important differences between these four states. But the cause of social backwardness in these four different States, nevertheless, appears to have much in common and recent comparative research has pointed to many similarities in the social, cultural and even political makeup of these states which have contributed to their backwardness.

Life in Uttar Pradesh is short and uncertain. Female expects to less than 55 years and the under-fire mortality rate is as high as 141 per thousands. In these respects Uttar Pradesh. The probability that she will die before the age of one is more than six times as higher in Uttar Pradesh than in Kerala. According to the recent National Family Health survey (NFHS-3), Uttar Pradesh comes second to Bihar among the major Indian states in terms of the incidence of under nutrition among children below the age of five. This corroborates as well as explain to a large extent the lower the possibility of child survival in Uttar Pradesh. Further, the demographic transition of U.P. has been slow. Among all the major Indian states, Uttar Pradesh has the highest birth rate and the highest fertility rate (Arnold et al., 2009).

The problems of education system are exacting. Due to public apathy the school is in disarray, privately run school are functional, but beyond the reach of ordinary people. The State government has taken programs to make the population totally literate. There are special programs like the World Bank aided DPEP. Steps are being taken with the help of
NGOs and other organizations to raise popular participation. At the level of higher education and technical education Uttar Pradesh has 16 general universities, 3 technical universities, one Indian Institute of Technology (Kanpur), one Indian Institute of Management (Lucknow), one Indian Institute of Information Technology and large number polytechnics, engineering institutes and industrial training institutes. This provides the State with a firm basis for providing opportunities for higher education to its youth.

\section{Demographic Structure of Uttar Pradesh}

Availability of land \& natural resource and environment play an important role in the development of any country or states. But utilization of these resources and best use of economic development is possible only by people. People are searching and best utilize these natural resources according to their needs. That's why population is very important in economic development. So, it is necessary to understand the total population and its structure. Demographic characteristics of a country provide an overview of its population size, composition territorial distribution, changes therein, and the components of changes such as nativity, mortality, and social mobility. This section on demographic indicators has been subdivided into two parts- population Statistics and Vital Statistics. Population statistics include indicators that measure the population size, sex ratio, density and dependency ratio, while vital statistics include indicators such as birth rate, death rate, and natural growth rate, life expectancy at birth, mortality and fertility rates. These indicators for the country as well as states will help in identifying areas that need policy and programmed interventions, setting near and far-term goals, and deciding priorities, besides understanding them in an integrated structure.

\section{Population Growth Rate}

Uttar Pradesh is the most populous state in the Country. Table 1; shows the population growth rate of Uttar Pradesh and India since 1901 to 2011. As per details from Census 2011, Uttar Pradesh has a population of 19.98 Crores, an increase from the figure of 16.62 Crore in 2001 census. The total population of Uttar Pradesh as per 2011 census is 19.96 crore as compared to 16.62 crore in 2001. The total population growth in this decade was 20.23 percent, while in previous decade it was 25.80 percent. The population of Uttar Pradesh forms 16.51 percent of India in 2011. In 2001, the figure was 16.16 percent. Further Table 1; shows that there was a many step of population growth rate since 1901 . During 1901 to 2011, the population of Uttar Pradesh is increased from 4.86 crore to 16.62 crore. In the last 100 years, the state population has become 4.1 times where is the country's population has been increased 5 times. If we divided this period into two parts, i.e. 1901 to 1951 and 1951 to 2011 , then we found that from 1901 to 1951 the state population has been increased by only 30 percent. And in the second period, i.e. 1951 to 2011 the population has been 
increased 216 percent, a very high rate. This result shows that population growth rate was higher after independence as compared to before. On the other hand, the growth rate of population is lower in Uttar Pradesh as compare to national level in both the periods.

When we see the decade growth rate, we found that in the earlier period, it was negative, after that it increased. After 1951, population growth rate in Uttar Pradesh has been increasing continuously (table 1\&2). After 1981, population has been growing more than at a rate of 20 percent with each decade. It is a serious problem and will be more dangerous in the future. After 1951, annual population growth rate was 1.1 percent, while during 1981 to 2001 this growth rate is more than 25 . From 2001 to 2011, population growth rate shows a decline, but still its in higher side.

When we compare the Uttar Pradesh population growth rate in national level, we found many interesting facts. Since census year 1901 to 1971 , the growth rate of population of
Uttar Pradesh have been lower as compare to national level. And the difference was higher. As in 1911, when the population has decreased as compared to the last decade, while at national level it has increased by 5.7 percent. Likewise, in 1931, 1961 and 1971, the population growth of Uttar Pradesh was 5-6 percent less than national level. But since 1981, population growth rate shows a decline trend at the national level and in case of Uttar Pradesh it has been increasing year to year continuously. Comparison of Uttar Pradesh and Indian population growth rate also seen in terms of percentage share of Uttar Pradesh in national population. In the initial period, due to lower rate of population growth rate, the percentage share of Uttar Pradesh in national level has been decreased. In 1901, the percentage share of the Uttar Pradesh population in the total population was 20.39 percent, which has been declining 16.10 percent in 1971 (Table 1.). But after that Uttar Pradesh's population share shows a little increased in total population.

Table 1: Population Growth rate of Uttar Pradesh and India (1901 to 2011)

\begin{tabular}{|l|l|l|l|l|l|}
\hline \multirow{2}{*}{ Years } & Uttar Pradesh (Lakhs) & \multirow{2}{*}{ India (Lakhs) } & \multirow{2}{*}{ Share of Uttar Pradesh in India (\%) } & \multicolumn{3}{|l|}{ Decadal Growth Rate (\%) } \\
\cline { 5 - 7 } & & & Uttar Pradesh & India \\
\hline 1901 & 486 & 2384 & 20.39 & -- & - \\
\hline 1911 & 482 & 2521 & 19.12 & $(-0.97)$ & $(+5.75)$ \\
\hline 1921 & 467 & 2513 & 18.58 & $(-3.08)$ & $(-0.31)$ \\
\hline 1931 & 498 & 2790 & 17.85 & $(+6.66)$ & $(+11.00)$ \\
\hline 1941 & 565 & 3187 & 17.73 & $(+13.57)$ & $(+14.22)$ \\
\hline 1951 & 632 & 3611 & 17.50 & $(+11.82)$ & $(+13.31)$ \\
\hline 1961 & 737 & 4392 & 16.78 & $(+16.66)$ & $(+21.51)$ \\
\hline 1971 & 883 & 5482 & 16.11 & $(+19.78)$ & $(+24.80)$ \\
\hline 1981 & 1109 & 6833 & 16.23 & $(+25.49)$ & $(+24.64)$ \\
\hline 1991 & 1320 & 8463 & 15.60 & $(+25.55)$ & $(+23.86)$ \\
\hline 2001 & 1662 & 10286 & 16.16 & $(+25.80)$ & $(+21.34)$ \\
\hline 2011 & 1996 & 12102 & 16.49 & $(+20.09)$ & $(+17.64)$ \\
\hline
\end{tabular}

Source: Census of India, www.censusindia.gov.in

Tables 2: Population Growth in Uttar Pradesh (1901 to 2011)

\begin{tabular}{|l|l|l|}
\hline Years & Population (Lakhs) & Annual Growth Rate (\%) \\
\hline 1901 & 486 & - \\
\hline 1911 & 482 & -0.08 \\
\hline 1921 & 467 & -0.32 \\
\hline 1931 & 498 & 0.64 \\
\hline 1941 & 565 & 1.27 \\
\hline 1951 & 632 & 1.13 \\
\hline 1961 & 738 & 1.56 \\
\hline 1971 & 883 & 1.81 \\
\hline 1981 & 1109 & 2.31 \\
\hline 1991 & 1320 & 2.29 \\
\hline 2001 & 1662 & 2.33 \\
\hline 2011 & 1996 & 1.85 \\
\hline
\end{tabular}




\section{Population Density and Sex Ratio}

Experience shows that a very populous city can rarely, if ever, be well governed. To the size of states there is a limit, as there is to other things (plants, animals, implements), for none of these retain their natural power when they are too large or too small. 'Density of Population' is denned as the number of persons per square kilometer. It is an important index of population which shows concentration of population in a particular area. As per the Census 2011, the population density of India has gone up to 382 persons per square kilometer from 325 persons per square kilometer in 2001. On an average, 57 more people inhabit every square kilometer in the country as compared to a decade ago. In the state, the density of population is 828 in Census 2011 as compared to 690 in Census 2001. The population density of Uttar Pradesh from 1901 to 2011 is shown in table 3. At the beginning of the twentieth century i.e. in 1901 the density of Uttar Pradesh was as low as 165 persons per sq. $\mathrm{km}$. This steadily increased in each decade to reach 828 persons per sq. $\mathrm{km}$. in 2011 which is higher than national average. This constitutes a 17.5 percent increase over 2001 .

\section{Sex Ratio}

It is defined as the number of females per thousand males. It is an important social indicator to measure the equality between males and females in a society at a given period of time. According to 2011 census the sex ratio is 933 . The sex ratio from 1901-2011 is given in Table 1.3. In the beginning of 20th century sex ratio was 972 and thereafter is recorded a sharply declining trend. The lowest sex ratio was in 1971 when it was only 927 females on per 100 males. It may be explained into socio-cultural factors and the pre-natal sex determination. Sex ratio in Uttar Pradesh is 912 i.e. for each 1000 male, which is below national average of 940 as per census 2011 but it is higher from 2001 (898).

In the beginning of 1901 sex ratio was at the level of 942 on per thousand males in Uttar Pradesh. Later on it moral towards downward and it reached at 876 in 1971. The data shows that in 1981 the sex ratio made slightly the attitude by 6 points and it reaches at 982 in comparison to 976 in 1971. But it could not stay itself in this trend slipped down by 882 to 876 in 1991.Later the census year 2001 data recorded a positive trend. it increase in 2001 as compare to last decade and further show the positive change in 2011 as compare to 2001. But sex ratio is still in lower side not only from national level but overall also. The possible factors are marital status poverty, son preference and female feticide etc.

Table 3: Sex ratio and Population Density in India and Uttar Pradesh (1901 to 2011)

\begin{tabular}{|l|l|l|l|l|}
\hline \multirow{2}{*}{ Years } & \multicolumn{3}{|c|}{ India } & \multicolumn{2}{c|}{ Uttar Pradesh } \\
\cline { 2 - 6 } & Sex Ratio & $\begin{array}{l}\text { Population Density } \\
\text { (Population per Seq. Km) }\end{array}$ & Sex Ratio & $\begin{array}{l}\text { Population Density } \\
\text { (Population per Seq. Km) }\end{array}$ \\
\hline 1901 & 972 & 77 & 942 & 165 \\
\hline 1911 & 964 & 82 & 916 & 164 \\
\hline 1921 & 955 & 81 & 908 & 159 \\
\hline 1931 & 950 & 90 & 903 & 169 \\
\hline 1941 & 945 & 103 & 907 & 192 \\
\hline 1951 & 946 & 117 & 908 & 215 \\
\hline 1961 & 941 & 142 & 907 & 251 \\
\hline 1971 & 930 & 177 & 876 & 300 \\
\hline 1981 & 934 & 216 & 882 & 377 \\
\hline 1991 & 927 & 267 & 876 & 548 \\
\hline 2001 & 933 & 325 & 898 & 690 \\
\hline 2011 & 940 & 385 & 912 & 828 \\
\hline
\end{tabular}

Source: Census of India, www.censusindia.gov.in 


\section{Literacy Rate}

Literacy is a perceptive indicator of cultural development of an area. Literacy helps a social group to acquire a higher social status through the process of social mobility in the States. The United Nations Educational, Scientific and Cultural Organization (UNESCO) has defined literacy as the, ability to identify, understand, interpret, create, communicate and compute, using printed and written materials associated with varying context. Literacy involves a process of learning to enable an individual to achieve his or her goals to develop his or her knowledge and potential and to participate fully in the wider society (Dana, 1993). Literacy is one of the key socioeconomic indicators which helps map the development path of a state. A common thread among developing states is the wide gender disparity in terms of literacy status. Similarly, in Uttar Parades there exists a gender gap in male and female literacy rates, with a favorable trend observed in regard to the former. In 1951, literacy rate in Uttar Pradesh was only 12 percent in which female literacy rate was only 4 percent. After 1951 literacy rate has been continuously increasing due to government efforts and people awerness. In 1981, it was reach at 32.5 percent but female literacy rate has been still lower level. Female literacy rate was only 16.7 percent. After this so many efforts has been done to increase the literacy rate and especially female literacy rate not only at regional \& national level but at International level also. Many International Organisations is playing an important role to increase the literacy rate in India. That's why, the literacy rate of male and females in Uttar Pradesh in 2011 has been reach at 79.20 percent and 59.3 percent, respectively, the literacy rate has been on the increase, with a sharp step-up in the latest 2001-2011 decade as shown below (Table 4). As per 2011 census, the literacy rate is 69.7 percent which is a 23.80 percentage point rise over the previous rate of 2001 at 56.3 percent. However, the gap between male literacy rates 79.2 percent and female literacy rate 59.3 percent is very high in Uttar Pradesh. If female literacy is increased, it will leads overall literacy also.to increase literacy rate, we can remove many social malaises and move forwarded to economic development. For this not only Government efforts but people awareness is also very important so that we can achieve this goal.

The demographics population of Uttar Pradesh is a multifarious subject, which is undergoing dynamic change. Uttar Pradesh is India`s most populous state. To understand the population it is very important to understand its all charterstic in which age composition has an important role. Uttar Pradesh would be the world's fifth most populous state, after only to China, India, the United States of America and Indonesia. It has a population of about 19.96 crores as per the 2011 census. Table 5; shows that age composition of Uttar Pradesh in three age-groups. Population in the age-group 0-14 is come under in consumer category not producer. But population under the age-group of 15-59 play an important role in production function along with consumption. People above 60 years, gradually weak physically and became a part of consumer age group. The data shows that in Uttar Pradesh 51.5 percent population is between the 15-59 age groups in 2001 which is slightly increased by around 4 points and in 2011 working age group population share is became 55.8 percent. Still, almost half of population in Uttar Pradesh is depended population. Percentage share of $0-14$ age group population which is more than 35 percent in 2011 shows that in future population growth rate will high and share of youth population will be increased. Increasing share of youth population will be beneficial for state development.

Table 4: Literacy Rate in Uttar Pradesh (Percent)

\begin{tabular}{|l|l|l|l|}
\hline Years & Total Persons & Male & Female \\
\hline 1951 & 12.02 & 19.17 & 4.07 \\
\hline 1961 & 20.87 & 32.08 & 8.36 \\
\hline 1971 & 23.99 & 35.01 & 11.23 \\
\hline 1981 & 32.65 & 46.65 & 16.74 \\
\hline 1991 & 40.71 & 54.82 & 24.37 \\
\hline 2001 & 56.30 & 68.80 & 42.20 \\
\hline 2011 & 67.68 & 77.28 & 57.18 \\
\hline
\end{tabular}

Source: Census of India, www.censusindia.gov.in

Percentage share of old population shows a little increseas in 2011 as compare to 2001 census of India. It is a little bit which also shows the efforts made for quality of life. It is a very important thing that share of population between 0-14 age group in total population is more than 35 percent. There are different meaning of this. Firstly we can say that in near future population growth will not be sustain which leads a high population growth. Secondly, a big size of nonproductive population which will be obstacle in the fast growing economic development of State. But in spite of that, in present environment, more availability of younger population which is working population also will make profitable and gainful for state through proper planning and it is called population dividend. 
S.K. Baliyan (2016) Int. J. Soc. Sc. Manage. Vol. 3, Issue-4: 228-238

Table 5: Distribution of Population in Uttar Pradesh by Age Groups (2011)

\begin{tabular}{|l|l|l|l|l|l|l|l|l|l|}
\hline \multirow{2}{*}{$\begin{array}{l}\text { Age } \\
\text { Groups }\end{array}$} & \multicolumn{3}{|c|}{ 2011 } & \multicolumn{3}{c|}{ 2001 } & \multicolumn{3}{c|}{1991} \\
\cline { 2 - 10 } & Persons & Males & Females & Persons & Males & Females & Persons & Males & Females \\
\hline $0-14$ & 35.7 & 36.0 & 35.4 & 40.9 & 40.8 & 40.9 & 40.0 & 40.6 & 40.3 \\
\hline $15-59$ & 55.8 & 55.5 & 56.1 & 51.5 & 51.9 & 51.7 & 52.0 & 52.3 & 52.1 \\
\hline $60+$ & 7.7 & 7.7 & 7.8 & 7.6 & 7.3 & 7.4 & 8.0 & 7.1 & 7.6 \\
\hline ANS & 0.8 & 0.8 & 0.8 & -- & -- & -- & -- & -- & -- \\
\hline Total & 100.0 & 100.0 & 100.0 & 100.0 & 100.0 & 100.0 & 100.0 & 100.0 & 100.0 \\
\hline
\end{tabular}

Source: Census of India, www.censusindia.gov.in

Table 6: Classification of Village and Towns in Uttar Pradesh: 2011

\begin{tabular}{|l|l|l|l|l|l|}
\hline \multirow{2}{*}{ Population groups } & \multicolumn{3}{|c|}{ Village } & \multicolumn{2}{c|}{ Towns } \\
\cline { 2 - 6 } & Numbers & $\begin{array}{l}\text { Share of Total } \\
\text { Villages } \\
\text { Population }\end{array}$ & Population & Numbers & $\begin{array}{l}\text { Share of Total } \\
\text { Towns Population }\end{array}$ \\
\hline$>200$ & 7832 & 0.45 & 706258 & - & - \\
\hline $201-499$ & 13591 & 3.13 & 4854219 & - & - \\
\hline $500-999$ & 23381 & 11.12 & 17274576 & - & - \\
\hline $1,000-1,999$ & 28020 & 25.82 & 40099869 & 01 & 0.01 \\
\hline $2,000-4,999$ & 21013 & 40.33 & 62642523 & 11 & 0.14 \\
\hline $5,000-9,999$ & 3432 & 14.45 & 22436278 & 133 & 3.04 \\
\hline $10,000-19,999$ & 545 & 4.70 & 7303555 & 258 & 10.52 \\
\hline $20,000-49,999$ & & 0.00 & 0 & 181 & 15.40 \\
\hline $50,000-99,999$ & & 0.00 & 0 & 51 & 9.88 \\
\hline $1,00,000<$ & & 0.00 & 0 & 54 & 61.20 \\
\hline Total & & 100.00 & 155317278 & 689 & 100.00 \\
\hline
\end{tabular}

Source: Census of India, www.censusindia.gov.in Note: \# vaule in census, 2001.

\section{Village and Town population in Uttar Pradesh}

To see the world population, we found that as economic development take place, share of urban population in total population has been increased. It is also said that as urbanization has increased, economic development also increased. This is not fully applicable on Uttar Pradesh as well as India but it is considered that urbanization is an indicator of Development. According to 2011 census 77.7percent population is living in rural area and urban population share is only 22. 2 percent in Uttar Pradesh which is lesser the national level (31.2 percent in Urban and 68.8 percent in Rural Area in India) (Table 6).

Table 7; shows that percentage Share of religious population in total population In Uttar Pradesh and India. The data shows that in Uttar Pradesh as well as at National level, percentage share of hindu population is highest in total population. The muslim population has next highest share which is 18.5 percent. Percentage share of Muslim population in UP is $18.5 \%$ which is higher than national level $(13.4 \%)$. percentage share of population from other community in Uttar Pradesh is very less. i.e. Christions $(0.1 \%)$, Sikkhs $(0.4 \%)$, Budhdists $(0.2 \%)$ and Jains $(0.1 \%)$. In contrast, in India percentage share of these communities is comparatively high.

Table 7: Percentage Share of Population in Uttar Pradesh and India by Majors Religions, 2001

\begin{tabular}{|l|l|l|}
\hline \multirow{2}{*}{ Religions } & \multicolumn{2}{|c|}{ Percentage Share } \\
\cline { 2 - 3 } & Uttar Pradesh & India \\
\hline Hindu & 80.6 & 80.5 \\
\hline Muslims & 18.5 & 13.4 \\
\hline Christions & 0.1 & 2.3 \\
\hline Sikkhs & 0.4 & 1.9 \\
\hline Budhdists & 0.2 & 0.8 \\
\hline Jains & 0.1 & 0.4 \\
\hline Others unclassified Religion & 0.0 & 0.6 \\
\hline
\end{tabular}

Source: Census of India, www.censusindia.gov.in. 
Table 8: Population and growth of Scheduled Castes in Uttar Pradesh (Numbers in Lakhs)

\begin{tabular}{|l|l|l|l|l|l|}
\hline \multirow{2}{*}{ Years } & Total Population & \multirow{2}{*}{ Population of Scheduled castes } & Percentage Share & \multicolumn{2}{|c|}{ Decadal growth rate (\%) } \\
\cline { 5 - 7 } & & & & & \\
\hline 1961 & 737 & 185.5 & 21.0 & 19.80 & \\
\hline 1971 & 883 & 234.5 & 21.2 & 25.50 & 20.5 \\
\hline 1981 & 1109 & 292.8 & 21.0 & 25.50 & 24.8 \\
\hline 1991 & 1320 & 351.5 & 21.2 & 25.90 & 25.3 \\
\hline 2001 & 1662 & 413.6 & 20.7 & 20.08 & 17.66 \\
\hline 2011 & 1996 & & & & Schedules castes \\
\hline
\end{tabular}

Source: Census of India, www.censusindia.gov.in

Uttar Pradesh has a large population and a high population growth rate. Its population increased by over 25.90 percent and 20.08 percent between 1991 to 2001 and 2001 to 2011 respectively. It is clear from the Table 8 that decadal growth in Scheduled Caste population from 2001 to 2011 was 17.66 percent that was a little less than the corresponding growth of 20.08 percent in total population in the State, which may be taken as a healthy trend. Out of total population of India, the Scheduled Castes population accounts for only 16.23 percent while Uttar Pradesh has 20.7 percent Scheduled Caste population in 2011. Year wise Total and Scheduled Caste population as per 2011 census are summarized in the following table8. Data shows that scheduled caste population share in total population is 20.7 percent in 2011 which is lesser that the last decade. In 2001 it was 21 percent and this share is still stagnant at that level from 1961

\section{Literacy rate of Total Population and Scheduled Castes in Uttar Pradesh}

The Scheduled Castes belong to the poor section of the society. For historical reasons, Scheduled Castes remained socially and economically neglected since long and were deprived from the basic amenities essential for civilized world. In view of it, "Growth with Social Justice" has been made an avowed objective of planning process since its inception. Constitutional provisions have been made for the promotion and protection of their interest. Directive Principles of the State Policy under Article-46 of the constitution of India also lays emphasis upon their welfare, which reads as follows:

\section{"The State shall promote with special care theeducational and economic interests of the weaker sectionsof the people, and, in particular, of the Scheduled Castes and the Scheduled Tribes, and shall protect them fromsocial injustice and all forms of exploitation."}

The distribution Literacy rates of Total population and Scheduled Castes, of Uttar Padeshfrom 1971 to 2011 is given in Table 9. Majority of the Scheduled Castes population lives in rural areas. The poverty ratio, size of the land holding, occupational classification and number of main workers and pattern are important parameters to judge the rural economy. Most of the Scheduled Castes family are still living below the poverty line and also majority of then are engaged in low wages and even obnoxious and degraded occupations like sweeping and scavenging. Their skill base is rather weak. Uttar Pradesh lags behind the all India average in terms of percentage population of Scheduled Castes living below poverty line in rural \& urban area.

According to 2011 census, the literacy rate among Scheduled Caste population in Uttar Pradesh was 50.7 percent as compared to 57.3 percent among total population. However, literacy among Scheduled Caste females is as low as 40.6 percent as compared to 48.4 percent literacy among total females. The literacy situation in Uttar Pradesh among this category vis-à-vis total population is shown in the Table 9. It is obvious from table that during the last two decades, the literacy rate of Scheduled Castes increased by $72.12 \& 9.50$ percent approximately whereas the corresponding increase for total population is $35.34 \& 1.78$ percent approximately. Literacy among Scheduled Caste female increased 8 times from 1991 to 2001 and 2001 to 2011. The latest estimate prepared by education department indicates that there is significant increase in the enrollment of female child belonging to Scheduled Castes but still concreted efforts are needed in this direction. In order to achieve the objectives, the State Government brought about significant policy changes for the implementation of Scheduled Caste Sub-Plan during the Ninth Five Year Plan, according to which, the Planning Department has been providing outlays under the Scheduled Caste Sub-Plan (SCSP) in proportion to Scheduled Caste population in the State. During the Tenth Five Year Plan, Social Welfare Department has been nominated as the nodal department for formulation, co-ordination and monitoring of Scheduled Caste Sub-Plan. 
Table 9: Trends of Literacy rate of Total Population and Scheduled Castes in Uttar Pradesh (\%)

\begin{tabular}{|l|l|l|l|l|l|l|}
\hline \multirow{2}{*}{ Years } & \multicolumn{3}{|c|}{ Total Population } & \multicolumn{3}{c|}{ Scheduled Castes } \\
\cline { 2 - 7 } & Male & Female & Total & Male & Female & Total \\
\hline 1971 & 31.5 & 10.6 & 21.7 & 17.1 & 2.5 & 10.2 \\
\hline 1981 & 38.8 & 14 & 27.2 & 24.8 & 3.9 & 15.0 \\
\hline 1991 & 55.7 & 25.3 & 41.6 & 40.8 & 10.7 & 26.9 \\
\hline 2001 & 68.8 & 42.2 & 56.3 & 60.3 & 30.5 & 46.3 \\
\hline 2011 & 65.3 & 48.4 & 57.3 & 59.8 & 40.6 & 50.7 \\
\hline
\end{tabular}

Source: Census of India, www.censusindia.gov.in

\section{Workers in Total Population in Uttar Pradesh}

Work is defined as participation in any economically production activity with or without compensation, wages or profit. Such participation may be physical and/or mental in nature. Work involves not only actual work but also includes effective management and direction of work. All persons engaged in 'work' as defined above are workers. The main point to note is that the activity should be economically productive. Another major weakness of Uttar Pradesh is low worker pareticipation. In Uttar Pradesh only 33 percent of the population is willing to work. However, this also depend upon the opportunities available in the States. Cultural taboos also play a major role. For example, women in Uttar Pradesh appear to be reluctant to go out of the house to work. In village generally, upper-class people do not favour working with their oun lands. "There is joy in work. There is no happiness except in the realization that we have accomplished something", written by Henry Ford.

The working population and work participation rate highlights the occupational distribution of a states. The information is essential for calculating state domestic product at factor cost popularly known as "State Income" for important tertiary sectors by adopting statistical methods of interpolation/extrapolation. The work force distribution also presents data regarding number of main and marginal workers. With the commencement of welfare schemes of the government, the percentage of main workers and marginal workers to total workers substantially from 22.34\& 10.60 percent in 2011 in Uttar Pradesh. The female work participation rate is very low in comparison to male counterpart for total, rural and urban population in India and Uttar Pradesh. In India, total female work participation rate is less than half of total male work participation rate and in urban areas of India it is less than a third. Work participation rate in rural area is higher as compare to urban area. Difference between rural and urban WPR is due to marginal worker. Marginal worker is very high in rural areas compare to urban area. Another thing which is important the female work participation rate (FWPR). FWPR is very low in Uttar Pradesh and it is worst in urban area as compare to rural area. If we want to increase WPR then we have to increase FWPR and also made efforts to increase female main worker (http://updes.up.nic.in/2.

Table 10: Percentage share of Workers in Total Population in Uttar Pradesh, 2011

\begin{tabular}{|c|l|l|l|l|}
\hline Area & Main Workers & Marginal Workers & Total Workers & Non Workers \\
\hline (A) Rural & 21.59 & 11.85 & 33.45 & 66.55 \\
\hline Male & 34.34 & 13.01 & 47.35 & 52.65 \\
\hline Female & 7.70 & 10.59 & 18.30 & 81.70 \\
\hline (B) Urban & 24.94 & 6.22 & 31.16 & 68.84 \\
\hline Male & 40.91 & 8.03 & 48.94 & 51.06 \\
\hline Female & 7.09 & 4.19 & 11.28 & 88.72 \\
\hline (C)Uttar Pradesh & 22.34 & 10.60 & 32.94 & 67.06 \\
\hline Male & 35.82 & 11.89 & 47.71 & 52.29 \\
\hline Female & 7.57 & 9.18 & 16.75 & 83.25 \\
\hline
\end{tabular}

Source: Census of India, www.censusindia.gov.in 
S.K. Baliyan (2016) Int. J. Soc. Sc. Manage. Vol. 3, Issue-4: 228-238

Table11: Selected Indicators of Human Development for Major States

\begin{tabular}{|c|c|c|c|c|c|c|c|c|}
\hline \multirow{2}{*}{ States } & \multicolumn{2}{|c|}{ Life expectancy } & \multicolumn{2}{|c|}{ Infant Mortality Rate, 2012} & \multicolumn{2}{|c|}{ Birth Rate, 2012} & \multicolumn{2}{|c|}{ Death Rate, 2012} \\
\hline & Male & Female & Total & Male & Female & Total & Total & Total \\
\hline Andhra Pradesh & 63.5 & 68.2 & 65.8 & 40.0 & 43.0 & 41.0 & 17.5 & 7.4 \\
\hline Assam & 61.0 & 63.2 & 61.9 & 54.0 & 57.0 & 55.0 & 22.5 & 7.9 \\
\hline Bihar & 65.5 & 66.2 & 65.8 & 42.0 & 45.0 & 43.0 & 27.7 & 6.6 \\
\hline Gujarat & 64.9 & 69.0 & 66.8 & 36.0 & 39.0 & 38.0 & 21.1 & 6.6 \\
\hline Haryana & 67.0 & 69.5 & 67.0 & 41.0 & 44.0 & 42.0 & 21.6 & 6.4 \\
\hline Himachal Pradesh & 67.7 & 72.4 & 70.0 & 35.0 & 38.0 & 36.0 & 16.2 & 6.7 \\
\hline Jammu \& Kashmir & 69.2 & 71.1 & 70.1 & 38.0 & 40.0 & 39.0 & 17.6 & 5.4 \\
\hline Karnataka & 64.9 & 69.7 & 67.2 & 30.0 & 34.0 & 32.0 & 18.5 & 7.1 \\
\hline Kerala & 71.5 & 76.9 & 74.2 & 10.0 & 13.0 & 12.0 & 14.9 & 6.9 \\
\hline Madhya Pradesh & 61.1 & 36.8 & 62.4 & 54.0 & 59.0 & 56.0 & 26.6 & 8.1 \\
\hline Maharashtra & 67.9 & 71.9 & 69.9 & 24.0 & 26.0 & 25.0 & 26.6 & 6.3 \\
\hline Odisha & 62.2 & 63.9 & 63.0 & 52.0 & 54.0 & 53.0 & 19.6 & 8.5 \\
\hline Punjab & 67.4 & 71.6 & 69.3 & 27.0 & 29.0 & 28.0 & 15.9 & 6.8 \\
\hline Rajasthan & 64.7 & 68.3 & 66.5 & 47.0 & 51.0 & 49.0 & 25.9 & 6.6 \\
\hline Tamil Nadu & 67.1 & 70.9 & 68.9 & 21.0 & 22.0 & 21.0 & 15.7 & 7.4 \\
\hline Uttar Pradesh & 61.8 & 63.7 & 62.7 & 52.0 & 55.0 & 53.0 & 27.4 & 7.7 \\
\hline West Bengal & 67.4 & 71.0 & 69.0 & 31.0 & 33.0 & 32.0 & 16.1 & 6.3 \\
\hline India & 64.6 & 67.7 & 66.1 & 41.0 & 44.0 & 42.0 & 21.6 & 7.0 \\
\hline
\end{tabular}

\section{Human Development Index (HDI)}

In any nation and states, Human Development Index (HDI) outcomes are a function of economic growth, social policy, and poverty reduction measures at the macro-level. The Human Development Index (HDI) is a composite index of outcome indicators in three dimensions:

1. A long and healthy life, as reflected in life expectancy at birth.

2. The acquisition of education and knowledge, as reflected in the mean years of schooling (adjusted for out of school children) and literacy rate (age 7 years and above).

3. The standard of living and command over resources, as reflected in the monthly per capita expenditure adjusted for inflation and inequality.

In 2010, India ranked 119 among 192 countries across the world, with a medium level HDI of 0.52 , moving one notch higher as compared to 2005. According to United Nations Development Programme (UNDP) data, it is among the top 10 movers in gross domestic product (GDP) growth. Table 11; presents data on HDI for different states for 2012. It is seen that the ranking of the states in terms of HDI has barely changed over this past decade. The generally well performing states are Kerala, Delhi, Himachal Pradesh, Goa, and Punjab, which occupy the first five places in the years. On the other hand, Bihar, Jharkhand, Madhya Pradesh, Uttar Pradesh, Orissa, Rajasthan, and Chhattisgarh appear at the bottom of the list in the years. Thus, despite some catching-up witnessed in the states with low human development, the progress has not been rapid enough to change the inter se ranking radically. The improvement in HDI for a state could be driven by the Income Index, the Education Index, or the Health Index, or a combination of the three indices. It is the improvement of the Education 
Index during the period 1999-2000 and 2011-12 that has driven India's HDI upwards, while the change in the Income Index (which in this case is really an indicator of the change in consumption rather than income per se) is only as large as the overall change in the HDI. The good news is that the poor states, by and large, have registered a significantly higher than average improvement in the Income Index. Similarly, the educationally backward and poorer states (Uttar Pradesh, Rajasthan, Orissa, Madhya Pradesh, Andhra Pradesh, and Bihar) are the ones which have shown the greatest improvement in the Education Index. The improvement in the Education Index in the educationally backward states suggests a strong trend of convergence in educational outcomes across states. Remarkably, the improvement in the Health Index during the period 19992000 to $2007-08$ is well below the improvement in the HDI overall. In other words, while the Income Index has improved at the same rate as the HDI for India, and the Education Index by much more than the improvement in the HDI, the Health Index has not shown any significant change; a subject that we return to later in this chapter, while examining the outcomes in health (http://indiabudget.nic.in/survey.asp).

\section{Conclusion}

People are searching and best utilize these natural resources according to their needs. The demographics population of Uttar Pradesh is a multifarious subject, which is undergoing dynamic change. To understand the population it is very important to understand its all charterstic in which age composition has an important role. The working population and work participation rate highlights the occupational distribution of a states. The information is essential for calculating state domestic product at factor cost popularly known as "State Income" for important tertiary sectors by adopting statistical methods of interpolation/extrapolation. The generally well performing states are Kerala, Delhi, Himachal Pradesh, Goa, and Punjab, which occupy the first five places in the years. The pace of urbanization has been lower in the state. The level of urbanization has also been lower than most other states. The numbers of urban centres with more than one lakh population have grown slowly over the last thirty years. The distinguishing feature of Uttar Pradesh's economy is its regional imbalances. In terms of economic indicators like agricultural productivity, infrastructural facilities, industrial growth, the Uttar Pradesh's economy can be categorized into five regions; Western, Eastern, Central, Ruhelkhand and Hill. Almost all social indicators of the state show that the state stands on a 13 th or 14th position among the sixteen major States. Bihar and in some cases Orissa, are the only two states which lag behind U.P. in terms of social development indicators like medical facilities, teacher-pupil ratio in primary schools, birth rate, death rate, infant mortality rate, literacy, per capita income, electrification of villages, per capita power consumption, etc.

The problems of education system are exacting. Due to public apathy the school is in disarray, privately run school are functional, but beyond the reach of ordinary people. Availability of land \& natural resource and environment play an important role in the development of any country or states. But utilization of these resources and best use of economic development is possible only by people. When we compare the Uttar Pradesh population growth rate in national level, we found many interesting facts. Since census year 1901 to 1971 , the growth rate of population of Uttar Pradesh have been lower as compare to national level. And the difference was higher. Experience shows that a very populous city can rarely, if ever, be well governed. To the size of states there is a limit, as there is to other things (plants, animals, implements), for none of these retain their natural power when they are too large or too small. 'Density of Population' is denned as the number of persons per square kilometer. It is an important index of population which shows concentration of population in a particular area. The posible factors are marital status poverty, son preference and female fatiside etc.

The demographic population of Uttar Pradesh is a multifarious subject, which is undergoing dynamic change. Uttar Pradesh is India`s most populous state. To understand the population it is very important to understand its all charterstic in which age composition has an important role. Uttar Pradesh would be the world's fifth most populous state, after only to China, India, the United States of America and Indonesia. It has a population of about 19.96 crores as per the 2011 census. Uttar Pradesh has a large population and a high population growth rate. Its population increased by over 25.90 percent and 20.08 percent between 1991 to 2001 and 2001 to 2011 recpectivily. Work is defined as participation in any economically production activity with or without compensation, wages or profit. Such participation may be physical and/or mental in nature. Work involves not only actual work but also includes effective management and direction of work. The main point to note is that the activity should be economically productive.

In 2010, India ranked 119 among 192 countries across the world, with a medium level HDI of 0.52, moving one notch higher as compared to 2005. According to United Nations Development Programme (UNDP) data, it is among the top 10 movers in gross domestic product (GDP) growth. It is seen that the ranking of the states in terms of HDI has barely changed over this past decade. The generally well performing states are Kerala, Delhi, Himachal Pradesh, Goa, and Punjab, which occupy the first five places in the years. On the other hand, Bihar, Jharkhand, Madhya Pradesh, Uttar Pradesh, Orissa, Rajasthan, and Chhattisgarh 
appear at the bottom of the list in the years. Thus, despite some catching-up witnessed in the states with low human development, the progress has not been rapid enough to change the inter se ranking radically. The improvement in HDI for a state could be driven by the Income Index, the Education Index, or the Health Index, or a combination of the three indices. The good news is that the poor states, by and large, have registered a significantly higher than average improvement in the Income Index. Similarly, the educationally backward and poorer states Uttar Pradesh, Rajasthan, Orissa, Madhya Pradesh, Andhra Pradesh, and Bihar are the ones which have shown the greatest improvement in the Education Index. The improvement in the Education Index in the educationally backward states suggests a strong trend of convergence in educational outcomes across states.

\section{References}

Agarwal MK (2013) Uttar Pradesh Ka Arthik Vikas. New Royal Book Company, ISBN: 9788189267827.
Arnold F, Parasuraman S, Arokiasamy P and Kothari M (2009) National Family Health Survey (NFHS-3) India 2005-06.

Census of India (2001 \& 2011) The Registrar General \& Census Commissioner, India, New Delhi, Ministry of Home Affairs, Government of India, www.censusindia.gov.in.

Dana D (1993) Gender Inequality in Education and Employment in the Scheduled Castes and Tribes of India. Population Research and Policy Review 12(1): 53-70.

Economic Survey (2013-14), Ministry of Finance, Government of India, http://indiabudget.nic.in/survey.asp

Gupta K, Kishor S and Vaidehi Y (2008) National family health survey (NFHS-3) India 2005-06 Uttar Pradesh March 2008, International Institute for Population Sciences (IIPS) and Macro International, Ministry of Health and Family Welfare Government of India. pp. 1-148.

National Family Health Survey (NFHS-3) India 2005-06 Uttar Pradesh March 2008

Statistical Diary (2013-14), Directorate of Economics \& Statistics, Planning Department, Government of Uttar Pradesh, Lucknow. 